\title{
Checklist of the family Culicidae (Diptera) in Finland
}

\author{
Larry Huldén', Lena Huldén² \\ I Finnish Museum of Natural History, Zoology Unit, P.O. Box 17, FI-00014 University of Helsinki, Finland \\ 2 University of Helsinki, Department of Agricultural Sciences, P.O. Box 27, FI-00014 University of Helsinki, \\ Finland \\ Corresponding author: Larry Huldén (larry.hulden@helsinki.fi)
}

Academic editor: J. Kahanpää | Received 17 April 2014 | Accepted 22 August 2014 | Published 19 September 2014

http://zoobank.org/D2FC411F-5C37-4202-8BE9-E05554ABFBDA

Citation: Huldén L, Huldén L (2014) Checklist of the Culicidae (Diptera) in Finland. In: Kahanpää J, Salmela J (Eds) Checklist of the Diptera of Finland. ZooKeys 441: 47-51. doi: 10.3897/zookeys.441.7743

\begin{abstract}
A checklist of the Culicidae (Diptera) recorded from Finland is provided.
\end{abstract}

\section{Keywords}

Checklist, Finland, Diptera, Culicidae, mosquitoes

\section{Introduction}

The family Culicidae comprises 3539 extant species world-wide. The Finnish fauna is relatively small in relation to world fauna. Because of medical importance this family has been extensively taxonomically studied but still new species are discovered. The generic and subgeneric classifications of Culicidae follow Reinert et al. 2009. Because of some confusing use of names in the first half of the twentieth century in the Finnish literature, all available names are included in the list for clarity. The most important work on the Finnish mosquitoes was done by Pirkka Utrio $(1975,1976,1977,1978,1979)$.

\section{Number of species:}

World: 3539 extant species +25 fossil species (Harbach 2014)

Europe: 104 species (Snow and Ramsdale 2004)

Finland: 38 species 


\section{Checklist}

suborder Nematocera Dumeril, 1805

infraorder Culicomorpha Hennig, 1948

superfamily Culicoidea Meigen, 1818

CULICIDAE Meigen, 1818

ANOPHELINAE Grassi, 1900

Anopheles Meigen, 1818

sg. Anopheles Meigen, 1818

Anopheles beklemishevi Stegni \& Kabanova, 1976

= maculipennis auct. in part

Anopheles claviger (Meigen, 1804)

Anopheles messeae Falleroni, 1926

= claviger (of Fabricius, 1805) auct. nec Meigen, 1804

= maculipennis auct. in part

CULICINAE Meigen, 1818

Aedes Meigen, 1818

Aedes cinereus Meigen, 1818

Aedimorphus Theobald, 1903

Aedes vexans (Meigen, 1830)

Coquillettidia Dyar, 1905

Coquillettidia richiardii (Ficalbi, 1889)

Culex Linnaeus, 1758

sg. Culex Linnaeus, 1758

Culex pipiens Linnaeus, 1758

Culex torrentium Martini, 1925

sg. Neoculex Dyar, 1905

Culex territans Walker, 1856

= apicalis auct. nec Adams, 1903

Culiseta Felt 1904

= Theobaldia Neveu-Lemaire, 1902 preocc.

sg. Culicella Felt, 1904

Culiseta morsitans (Theobald, 1901)

Culiseta ochroptera Peus, 1935

sg. Culiseta Felt, 1904

Culiseta alaskaensis (Ludlow, 1906)

Culiseta annulata (Schrank, 1776)

Culiseta bergrothi (Edwards, 1921)

= glaphyroptera auct. nec (Shiner, 1864)

Culiseta subochrea (Edwards, 1921)

Dabliana Reinert, Harbach \& Kitching, 2006

Dabliana geniculata (Olivier, 1791)

Ochlerotatus Lynch Arribalzaga, 1881 
sg. Ochlerotatus Lynch Arribalzaga, 1881

Ochlerotatus annulipes (Meigen, 1830)

Ochlerotatus euedes (Howard, Dyar \& Knab, 1913)

= beklemishevi Denisova, 1955

Ochlerotatus cantans (Meigen, 1818)

= waterhousei (Theobald in Waterhouse, 1905)

= maculatus auct. nec (Meigen, 1804)

= rusticus auct. nec (Rossi,1790)

Ochlerotatus caspius (Pallas, 1771)

Ochlerotatus cataphylla Dyar, 1916

Ochlerotatus communis (De Geer, 1776)

= nemorosus (Meigen, 1818)

Ochlerotatus cyprius Ludlow, 1920

$=$ freyi $\mathrm{Edwards}, 1921$

Ochlerotatus diantaeus Howard, Dyar \& Knab, 1912

Ochlerotatus dorsalis (Meigen, 1830)

Ochlerotatus excrucians (Walker, 1848)

Ochlerotatus flavescens (Müller, 1776)

$=$ lutescens (Fabricius, 1775)

$=$ variegatus (Schrank, 1781)

Ochlerotatus hexodontus Dyar, 1919

Ochlerotatus impiger (Walker, 1848)

$=$ parvulus (Edwards 1921)

= nearcticus auct. nec (Dyar, 1922)

Ochlerotatus intrudens Dyar, 1919

Ochlerotatus leucomelas (Meigen, 1804)

Ochlerotatus nigrinus (Eckstein, 1918)

= sticticus auct. nec Meigen 1828

Ochlerotatus nigripes (Zetterstedt, 1838)

= alpinus auct. nec (Linnaeus) nomen dubium

Ochlerotatus pionips Dyar, 1919

Ochlerotatus pullatus (Coquillett, 1904)

Ochlerotatus punctodes Dyar, 1922

Ochlerotatus punctor (Kirby, 1837)

Ochlerotatus riparius Dyar \& Knab, 1907

\section{Notes}

Anopheles maculipennis Meigen, 1818. Not recorded in Finland. All previous reports refer to An. messeae or An. beklemishevi.

Anopheles claviger (of Fabricius, 1805). Mistaken name usage for Anopheles maculipennis s. lat. in the early $20^{\text {th }}$ century Finnish literature which then followed the Italian tradition. 
Culex pipiens f. molestus Forskåhl, 1775. This is not a valid species level taxon. It is a man biting form of the mainly bird biting Culex pipiens. Both have been reported from Finland.

Dabliana geniculata (Oliver, 1791). A possibly occasional specimen of this species was collected in Western Finland, verified by Christine Dahl (Itämies 1981).

Ochlerotatus alpinus L. Frey (1921) included this invalid species name (see Harbach 2014 ) in the Finnish list with a question mark. Hellén (1931) withdrew it from the Finnish list. According to Utrio (1977), Frey refers to nigripes (Zetterstedt, 1838).

Ochlerotatus behningi Martini, 1926. The species is listed for both Finland and Sweden in Dahl (1997). Lundström et al. (2013) do not accept the report for Sweden because of absence of documented locality. Based on the same argument, we do not include this species in the Finnish list.

Ocblerotatus (Rusticoidus) rusticus (Rossi, 1790). Dahl (1997) listed this species for Finland. There are, however, no confirmed collections of the species in Finland. Frey (1921) listed Aedes maculatus Meigen (with A. waterhousei Theobald as a presumed synonym) from Finland. According to Natvig (1948), Meigen made a mistake in 1830 when he stated that "maculatus is the male of cantans" instead of "reptans is the male of cantans", leading to a switch in synonyms. According to Minar (1990) the correct combinations should be as follows: maculatus Meigen is a synonym of rusticus (Rossi) and both reptans (Meigen) and waterhousei (Theobald) are synonyms of cantans (Meigen). From this context, it is obvious that Frey refers to the common species cantans and not to the southern species rusticus.

Ochlerotatus sticticus (Meigen, 1838). The species was reported from Finland (Kilpisjärvi) by Frey (1932) and listed for Finland in Frey and Storå (1941). According to Natvig (1948) and Utrio (1979) this record refers to Aedes nigrinus (Eckstein). In addition, it was reported by Syrjämäki (1960) in Finland (Hanko: Tvärminne) but later withdrawn by the author according to Utrio (1979, personal communication). It was also included for Finland in Dahl (1997), probably based on the former reports. According to Gutsevich et al. (1970) this species occurs in Russian Karelia. Thus, $A$. sticticus is not included in the Finnish list.

Culex apicalis Adams, 1903. Originally reported by Martini (1928) from Finland. All European reports of this Nearctic species before 1950 represent the closely related Holarctic species Culex territans (Becker et al. 2003).

\section{References}

Becker N, Petrić D, Zgomba M, Boase C, Dahl C, Lane J, Kaiser A (2003) Mosquitoes and their control. Kluwer Academic / Plenum Publishers, New York, Boston, Dordrecht, London, Moscow, 498 pp. doi: 10.1007/978-1-4757-5897-9

Dahl C (1997) Diptera Culicidae, Mosquitoes. In: Nilsson AN (Ed) Aquatic Insects of North Europe - A taxonomic Handbook. Volume 2. Apollo Books, Stenstrup, 163-186. 
Frey R (1921) Provisorisk förteckning over Finlands culicider. Meddelanden af Societas pro Fauna et Flora Fennica 47: 98-102.

Frey R (1932) [Aedes sticticus Meigen, ny för Finland]. Notulae Entomologicae 12: 64-65.

Frey R, Storå R (1941) Enumeratio Insectorum Fenniae. VI. Diptera: Culicidae. Helsingin Hyönteisvaihtoyhdistys, Helsinki, 52 pp.

Gutsevich AV, Monchadskii AS, Stackelberg AA (1970) Fauna USSR. Diptera. III. 4. Mosquitoes. Family Culicidae. Nauka, Leningrad, 384 pp. [in Russian]

Hackman W (1980) Checklist of Finnish Diptera I. Nematocera and Brachycera. Notulae Entomologicae 60: 17-48.

Harbach R (2014) Mosquito Taxonomic Inventory. http://mosquito-taxonomic-inventory. info/valid-species-list [accessed July 29 $9^{\text {th }} 2014$ ]

Itämies J (1981) Aedes geniculatus Suomelle uusi hyttynen (Diptera, Culicidae). Notulae Entomologicae 61: 207-208.

Lundström JO, Schäfer ML, Hesson JC, Blomgren E, Lindström A, Wahlqvist P, Halling A, Hagelin A, Ahlm C, Evander M, Broman T, Forsman, Persson Vinnersten TZ (2013) The geographic distribution of mosquito species in Sweden. Journal of the European Mosquito Control Association 31: 21-35. http://e-m-b.org/sites/e-m-b.org/files/JEMCA\%2831\%2921-35.pdf

Martini E (1928) Dixinae und Corethrinae des Museums zu Helsingfors. Notulae Entomologicae 8: 33-35.

Minar J (1990) Family Culicidae. In: Soos A, Papp L, Oosterbroek P (Eds) Catalogue of palaearctic Diptera 2. Akademiai Kiadó, Budapest, 74-113.

Natvig LR (1948) Contributions to the knowledge of the Danish and Fennoscandian mosquitoes, Culicini. Norsk entomologisk Tidsskrift. Supplement 1: 1-567. http://www.mosquitocatalog.org/files/pdfs/094600-2.pdf

Reinert JF, Harbach RE, Kitching IJ (2009) Phylogeny and classification of Aedini (Diptera: Culicidae). Zoological Journal of the Linnean Society 157: 700-794. doi: 10.1111/j.10963642.2009.00570.x

Snow KR, Ramsdale CD (2004) Culicidae. In: Beuk P, Pape T, de Jong H (Eds) Fauna Europaea: Diptera. Fauna Europaea version 1.0. http://www.faunaeur.org [accessed July 29th 2014]

Syrjämäki A (1960) Preliminary observations on the daily rhythm of biting activity of some Aedes species (Dipt., Culicidae). Annales Entomologici Fennici 26: 92-97.

Utrio P (1975) Anopheles claviger (Meig.), Aedes pionips Dyar and A. beklemishevi Den. (Diptera, Culicidae) found in Finland. Notulae Entomologicae 55: 63-64. http://www.mosquitocatalog.org/files/pdfs/134700-0.pdf

Utrio P (1976) Identification key to Finnish mosquito larvae (Diptera, Culicidae). Annales Agriculturae Fenniae 15: 128-136. http://www.mosquitocatalog.org/files/pdfs/13470.pdf Utrio P (1977) A checklist of Finnish mosquitoes (Diptera, Culicidae, including Aedes annulipes, new to Finland. Notulae Entomologicae 57: 130-132. http://www.mosquitocatalog.org/ files/pdfs/134700-2.pdf

Utrio P (1978) Distribution of mosquitoes (Diptera, Culicidae) attracted by man in Finland in early July. Notulae Entomologicae 58: 107-114.

Utrio P (1979) Geographic distribution of mosquitoes (Diptera, Culicidae) in eastern Fennoscandia. Notulae Entomologicae 59: 105-123. http://www.mosquitocatalog.org/files/pdfs/134700-3.pdf 